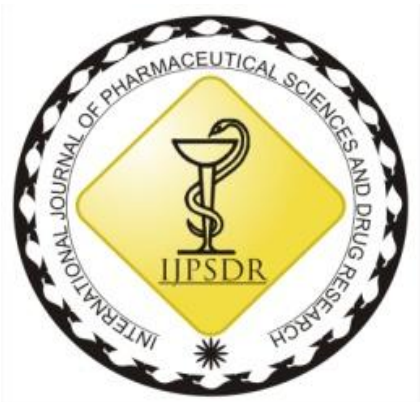

ISSN: 0975-248X

RESEARCH ARTICLE CODEN (USA): IJPSPP

$(\mathrm{cc})$ EY-No-sA

\title{
Antioxidant and antimicrobial activity of different plant parts of Anacardium occidentale L. and Mangifera indica L.: a comparative study
}

\author{
S. L Sija*, A. S Athulya, M. R Mahima, Ashok Vidhya \\ Department of Biotechnology, Sree Narayana College, Kollam - 691 001, Kerala, India
}

Copyright (C) 2019 S. L Sija et al. This is an open access article distributed under the terms of the Creative Commons Attribution-NonCommercialShareAlike 4.0 International License which allows others to remix, tweak, and build upon the work non-commercially, as long as the author is credited and the new creations are licensed under the identical terms.

\begin{abstract}
Anacardium occidentale L. and Mangifera indica L. has been used worldwide both for pharmaceutical, food and cosmetic industries due to the presence of biological activities of some of its metabolites. The present study comprises the correlation of antioxidant activity and antimicrobial activity in ethyl acetate extract of young leaves and bark of $A$. occidentale and $M$. indica. The activity of 1,1-diphenyl-2-picrylhydrazyl (DPPH) on radical scavenging effect of the extracts was carried out by spectrophotometrically. All the plant extracts showed DPPH radical scavenging activity and among the extracts, $A$. occidentale young leaves indicated higher antioxidant potential in comparison with those of the other extracts. The antibacterial activity of various extracts was also screened against some human pathogens of clinical importance; Pseudomonas aeruginosa; Salmonella typhi; Bacillus subtilis; Escherichia coli and Staphylococcus aureus.
\end{abstract}

Keywords: Anacardium occidentale, Mangifera indica, Antioxidant activity, Antibacterial activity, DPPH.

*Corresponding author: Dr. S. L Sija

Address: Department of Biotechnology, Sree Narayana College, Kollam - 691 001, Kerala, India

Tel.: +91-474-2741793, Fax: +91-474-2766857

E-mail $\bowtie$ : sijasl007@gmail.com

Relevant conflicts of interest/financial disclosures: The authors declare that the research was conducted in the absence of any commercial or financial relationships that could be construed as a potential conflict of interest.

Received: 16 May, 2019; Revised: 14 July, 2019; Accepted: 18 July, 2019; Published: 30 July, 2019

\section{INTRODUCTION}

Medicinal plants have become an element of international importance both in the case of medicinal and economical. The use of plant biochemical for therapeutic use is known since ancient time. Antioxidants have the ability to scavenge the free radicals found in a variety of food stuffs. Now a day, many antioxidants were extracted from plants to replace synthetic ones and also play a major role in protecting plants against harsh sunlight and live under severe oxygen stress. ${ }^{[1-4]}$ Vitamins, carotenoids and phenolic compounds are the major compounds that exhibit antioxidant activity. [5-6] Phenolics and flavonoids play a major role in contributing the antioxidant activity to the members of Anacardiaceae. [7-8] Considering this fact, the medicinally important tree species such as A. occidentale and M. indica were chosen for the evaluation of antioxidant property. It will help to find out new sources of natural antioxidants to use them in food industries and pharmaceutical industries to replace synthetic ones. 
The potent plant components can contest human and plant pathogenic bacteria, fungi and virus without any side effects and environmental hazards. Due to this favourable reason, search for plant products with antimicrobial properties intensified in recent years. [9-10] Microbial infections are one of the major reasons for physical disabilities, health problems and mortalities around the world. In medical field, phytochemicals have been used as antimicrobial agents. Compared to commercial antibiotics, natural phytochemicals are found to be more effective with fewer side effects that is why they are used as an alternate remedy for the treatment of various diseases. Bioactive compounds (alkaloids, tannins, flavonoids, phenolics etc.) also showed antimicrobial activity in the area of food preservation, pharmaceutics etc. Many pathogenic microbial species showed resistance to antibiotics has led to the screening of medicinal plants for their potential antimicrobial activities. ${ }^{[11-12]}$ Based on the role of plant extracts in curing many infectious diseases, the present study was carried at comparison of the antibacterial activity of various extracts of $A$. occidentale and $M$. indica. These plant extracts were investigated for antibacterial activity against selected pathogenic microbes (S. aureus, E. coli P. aeruginosa, S. typhi and B. cereus), that cause human skin disorders.

\section{MATERIALS AND METHODS}

\section{Plant materials}

Plant materials (young leaves and bark) of A. occidentale and $M$. indica were collected from the mother trees grown at the Sree Narayana College Campus, Kollam. The plant parts collected were cleaned and air-dried and later ground to fine powder.

\section{Preparation of plant extracts}

Powdered samples were extracted with ethyl acetate by maceration and kept it for a period of $24 \mathrm{hrs}$ at room temperature at a ratio of 1:100 (g: $\mathrm{ml})$. The samples were centrifuged at 10,000 rpm for 15 minutes and supernatants were collected. The filtered extract was concentrated in a rotary evaporator to remove ethyl acetate. The residue thus obtained was dissolved in ethyl acetate and kept at $4-8^{\circ} \mathrm{C}$ in a refrigerator. [11-12]

DPPH free radical scavenging activity

The DPPH free radical scavenging activity was assessed by the modified method. [13] DPPH (20 mg) was dissolved in ethyl acetate $(250 \mathrm{ml})$ in order to get the concentration of $80 \mu \mathrm{g} / \mathrm{ml}$. The plant extract was prepared in ethyl acetate $(1 \mathrm{mg} / \mathrm{ml})$. Serial dilutions were done to obtain concentration of 20,40,60, 80 and $100 \mu \mathrm{g} / \mathrm{ml}$. Ascorbic acid was used as standard (1$125 \mu \mathrm{g} / \mathrm{ml}$ ). Spectrophotometric reading was taken at $517 \mathrm{~nm}$ after 30 minutes dark incubation at room temperature. Freshly prepared DPPH solution in ethyl acetate was used for absorbance measurements. Percentage of inhibition was calculated using the following expression.

$$
\% \text { Inhibition }=\left(\mathrm{A}_{\text {control }}-\mathrm{A}_{\text {sample }} / \mathrm{A}_{\text {control }}\right) \times 100
$$

Non-linear regression analysis was used to calculate the concentration exhibiting $50 \%$ of DPPH free radical scavenging activity $\left(\mathrm{IC}_{50}\right)$.

\section{Antibacterial activities}

The antibacterial activity of the ethyl acetate extracts of various plant parts were carried out against some human pathogenic bacteria; Pseudomonas aeruginosa (MTCC 1034); Salmonella typhi (MTCC 1168); Bacillus subtilis (MTCC 2340); Escherichia coli (MTCC 56) and Staphylococcus aureus (MTCC 9760) obtained from the Microbiology Laboratory of the Department of Biotechnology, Sree Narayana College, Kollam, Kerala. Agar well diffusion method [14-15] was employed to assess the antibacterial activities of the different plant extracts using Mueller- Hinton agar plates. The bacteria ( $1 \mathrm{ml}$ bacterial broth of approximately $10^{5}$ cells) were swabbed with a sterile cotton swab into the MuellerHinton agar plates. The plant extract $(250 \mathrm{mg} / \mathrm{ml})$ was transferred to the well of $6 \mathrm{~mm}$ diameter. Then the microbial plates were incubated at $37^{\circ} \mathrm{C}$ for 24 hours. The zone of inhibitions produced by the inhibitory action of different plant extracts and control were taken as the antibacterial activity.

Statistical analysis

All the determinations were conducted at least 3 times $(\mathrm{n}=3)$; The statistical analysis was carried out using a SPSS (Chicago, IL) statistical software package (SPSS for Windows, ver.17, 2008). One way analysis (ANOVA) and the Duncan's New Multiple range test were applied to the result at 0.05 level of significance $(p<0.05)$.

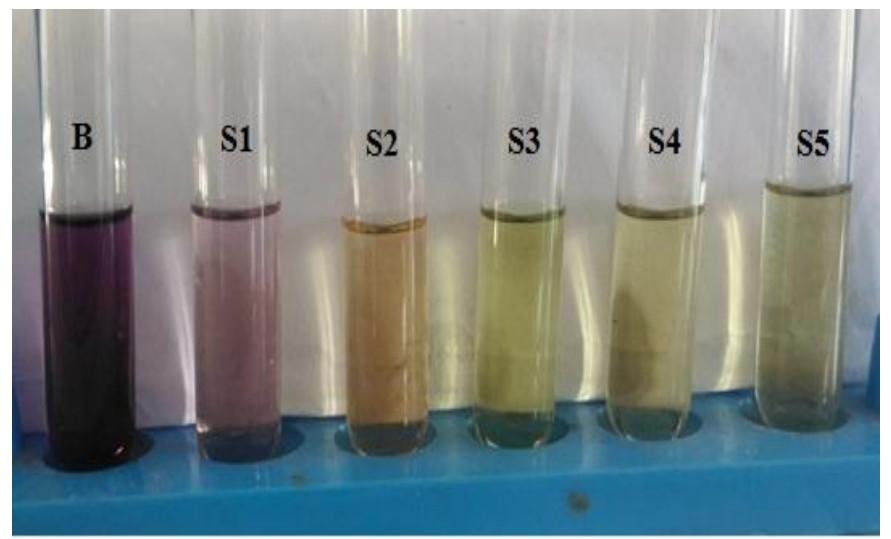

Fig. 1: Discoloration of DPPH under the influence of ascorbic acid at different concentrations $(25-125 \mu \mathrm{g} / \mathrm{ml})$

\section{RESULTS AND DISCUSSION}

\section{Antioxidant activity}

The antioxidant property of ethyl acetate extracts of various plant parts of $A$. occidentale and $M$. indica were determined using ethyl acetate solution of DPPH reagent along with ascorbic acid as standard. Antioxidant present in the given samples reacted with DPPH and its colour changed to yellow. The antioxidant activity of standard ascorbic acid at various concentrations is represented in Figure 1. The results of the present investigation showed that all the plant extracts showed antioxidant activity. Among various 
plant extracts of $A$. occidentale and $M$. indica checked for antioxidant activity, the various plant extracts of $A$. occidentale showed the maximal percent of inhibition compared to various plant extracts of $M$. indica.

In both the tree plants, antioxidant activity of various plant parts can be ranked as: young leaves > bark (Table 1). It was noticed that the DPPH radical scavenging activity was increased with the increase in the concentration of all the extracts from 20 to $100 \mu \mathrm{g} / \mathrm{ml}$. Among the four extracts and standard tested for antioxidant activity, the ethyl acetate extract of young leaves of $A$. occidentale revealed the topmost percent of inhibition from $36.44 \pm 0.58 \%$ at $20 \mu \mathrm{g} / \mathrm{ml}$ to $44.31 \pm 1.71 \%$ at $100 \mu \mathrm{g} / \mathrm{ml}$ while the ethyl acetate extracts of bark of $M$. indica showed the least (1.74 \pm $0.77 \%$ at $20 \mu \mathrm{g} / \mathrm{ml}$ and $9.47 \pm 1.55 \%$ at $100 \mu \mathrm{g} / \mathrm{ml})$, which is corresponding to the antioxidant activity of standard ascorbic acid $(45.25 \pm 0.36 \%$ at $20 \mu \mathrm{g} / \mathrm{ml}$ and $49.89 \pm$ $0.99 \%$ at $100 \mu \mathrm{g} / \mathrm{ml}$ ) (Table 1). Radical scavenging activities of plant phenolic compounds and the relationship between phenolic compounds and antioxidant activity was also studied [16] and many researchers have affirmed that phenolic compounds are most adequate antioxidants in $A$. occidentale. [17-18] Radical scavenging activity of ethanol extract of flower, leaves and stem bark of $A$. occidentale were explored. [19] The antioxidant activity of young leaves, barks, roots and kernels of $M$. indica were also studied. [20] Mangiferin is the most important phenolic compound present in the various parts of $M$. indica. [21]

The free radical scavenging activity of different plant part extracts of $A$. occidentale and $M$. indica were also expressed in terms of $\mathrm{IC}_{50}(\mu \mathrm{g} / \mathrm{ml})$ values (Table 2$)$ and

Table 1: Free radical scavenging activities of various extracts of $A$. occidentale and $M$. indica measured using the DPPH assay

\begin{tabular}{|c|c|c|c|c|c|c|}
\hline \multirow{3}{*}{\multicolumn{2}{|c|}{$\begin{array}{c}\text { Test compound } \\
\text { (Ethyl acetate extract) }\end{array}$}} & \multicolumn{5}{|c|}{ DPPH radical scavenging activity (\%) } \\
\hline & & \multicolumn{5}{|c|}{ Concentration $(\mu \mathrm{g} / \mathrm{ml})$} \\
\hline & & 20 & 40 & 60 & 80 & 100 \\
\hline \multirow{2}{*}{ A. occidentale } & Young leaves & $36.44 \pm 0.58$ & $38.11 \pm 1.34$ & $39.97 \pm 1.23$ & $41.96 \pm 0.91$ & $44.31 \pm 1.71$ \\
\hline & Bark & $10.34 \pm 0.94$ & $11.86 \pm 0.91$ & $15.17 \pm 1.48$ & $17.90 \pm 1.22$ & $19.1 \pm 1.33$ \\
\hline \multirow{2}{*}{ M. indica } & Young leaves & $31.33 \pm 0.63$ & $32.1 \pm 1.79$ & $34.3 \pm 0.87$ & $36.31 \pm 1.74$ & $37.91 \pm 1.23$ \\
\hline & Bark & $1.74 \pm 0.77$ & $3.51 \pm 0.64$ & $5.73 \pm 1.12$ & $7.14 \pm 1.68$ & $9.47 \pm 1.55$ \\
\hline Control & Ascorbic acid & $45.25 \pm 0.36$ & $46.43 \pm 1.97$ & $48.15 \pm 0.98$ & $49.1 \pm 0.86$ & $49.89 \pm 0.99$ \\
\hline
\end{tabular}

Results are expressed as means \pm SD for triplicates

\begin{tabular}{ccc}
\multicolumn{2}{c}{ Table 2: Antioxidant activity of investigated plant extracts of $\boldsymbol{A}$. occidentale and $\mathbf{M}$. indica } \\
\hline \multicolumn{2}{c}{ Test compound (ethyl acetate extract) } & $\mathbf{I C}_{50}(\boldsymbol{\mu g} / \mathbf{m l})$ \\
\hline \multirow{2}{*}{ A. occidentale } & Young leaves & $160.39 \pm 1.74 \mathrm{~b}$ \\
& Bark & $358.18 \pm 0.97 \mathrm{~d}$ \\
M. indica & Young leaves & $239.59 \pm 1.28 \mathrm{c}$ \\
Control & Bark & $526.29 \pm 1.71 \mathrm{e}$ \\
\hline
\end{tabular}

The mean $( \pm$ SD) values within a column followed by different letters are significantly different by

Duncan's multiple range test $(p<0.05)$

Table 3: Zones of inhibition produced by ethyl acetate extracts of A. occidentale and M. indica

\begin{tabular}{|c|c|c|c|c|c|c|}
\hline \multirow{3}{*}{\multicolumn{2}{|c|}{$\begin{array}{c}\text { Test compound } \\
\text { (Ethyl acetate extract) }\end{array}$}} & \multicolumn{5}{|c|}{ Zone of inhibition (mm) } \\
\hline & & \multicolumn{5}{|c|}{ Bacteria } \\
\hline & & P. aeruginosa & S. typhi & B. subtilis & E. coli & S. aureus \\
\hline \multirow{2}{*}{ A. occidentale } & Young leaves & 24 & 19 & 20 & 23 & 23 \\
\hline & Bark & 9 & - & 9 & 13 & - \\
\hline \multirow{2}{*}{ M. indica } & Young leaves & 25 & 14 & 24 & 19 & 19 \\
\hline & Bark & 9 & - & 12 & 9 & 13 \\
\hline
\end{tabular}

Young leaves $\left(\mathrm{C}_{1}\right)$, Bark $\left(\mathrm{C}_{2}\right)$ - A. occidentale; Young leaves $\left(\mathrm{M}_{1}\right)$, Bark $\left(\mathrm{M}_{2}\right)$ - M. indica 
It was recognized that ethanol extract of stem bark showed the zone of inhibition of $12.5 \mathrm{~mm}$ and cashew leaves showed the zone of inhibition of $13 \mathrm{~mm}$ against S. aureus. [22] Thus the present study is in conformity with early reports. The antimicrobial properties of various plant parts of $A$. occidentale are mainly due to the presence of a phenolic lipid known as anacardic acid and other chemical compounds such as tannins, flavonoids, phenols, alkaloids, saponins, steroids or triterpenes. [23-24]

Result of the current study also detected that ethyl acetate extract of young leaves and bark of $M$. indica showed zone of clearance against $P$. aeruginosa, $B$. subtilis, E. coli and S. aureus. It was observed that among the two extract of $M$. indica, ethyl acetate extract of young leaves demonstrated relatively great antimicrobial activity against $P$. aeruginosa with a zone of inhibition $25 \mathrm{~mm}$. It also showed $19 \mathrm{~mm}$ zone of inhibition against $S$. aureus, $24 \mathrm{~mm}$ zone of inhibition against B. subtilis (Table 3 \& Fig. 3 ).

It was also observed that young leaf extract of $M$. indica showed maximum zone of inhibition $(25 \mathrm{~mm})$ against $P$. aeruginosa compared to the young leaf extract of $A$. occidentale (24 mm) (Table 3 \& Fig. 3).
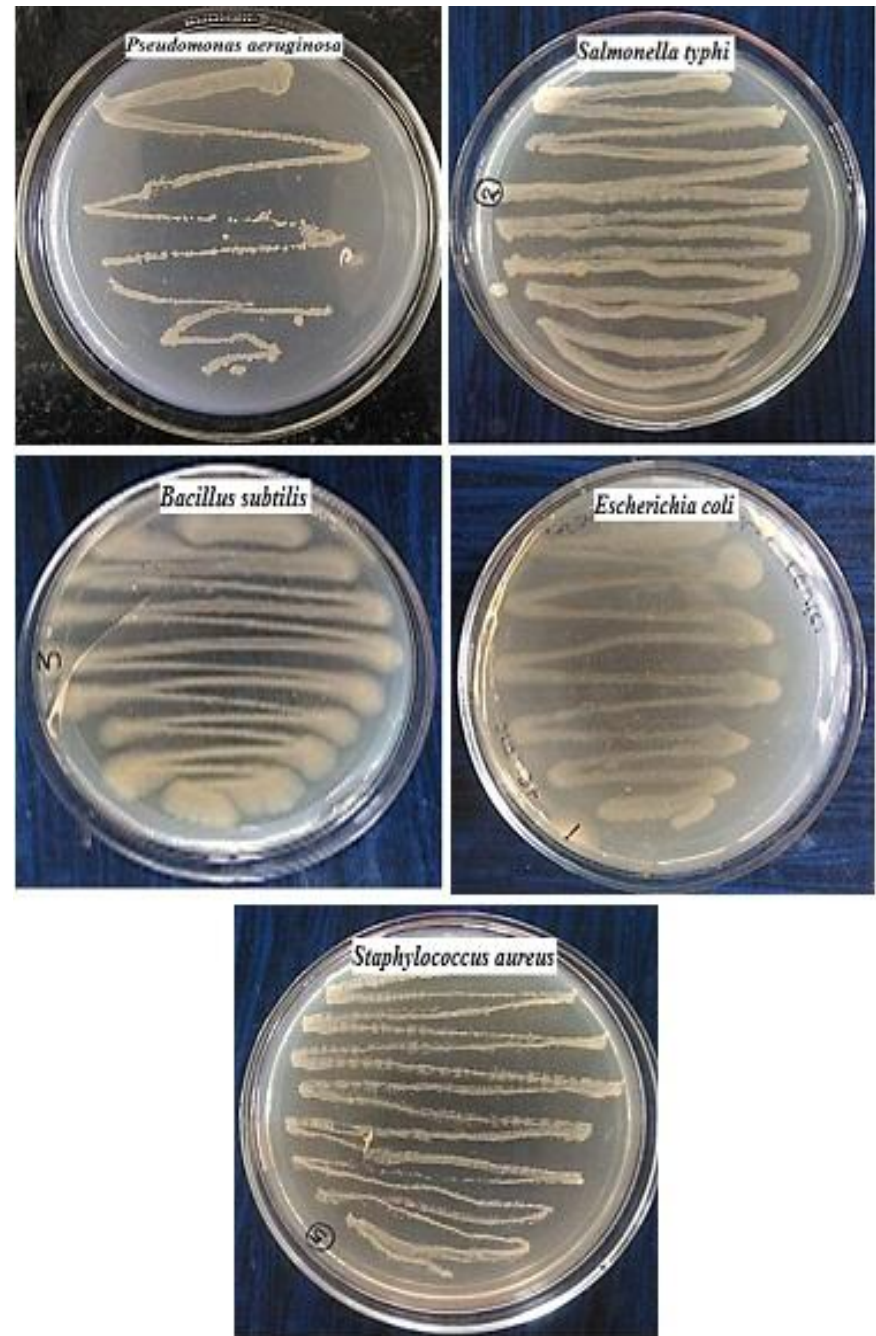

Fig. 2: Pure cultures of P. aeruginosa; S. typhi; B. subtilis; E. coli and $S$. aureus on nutrient agar plate
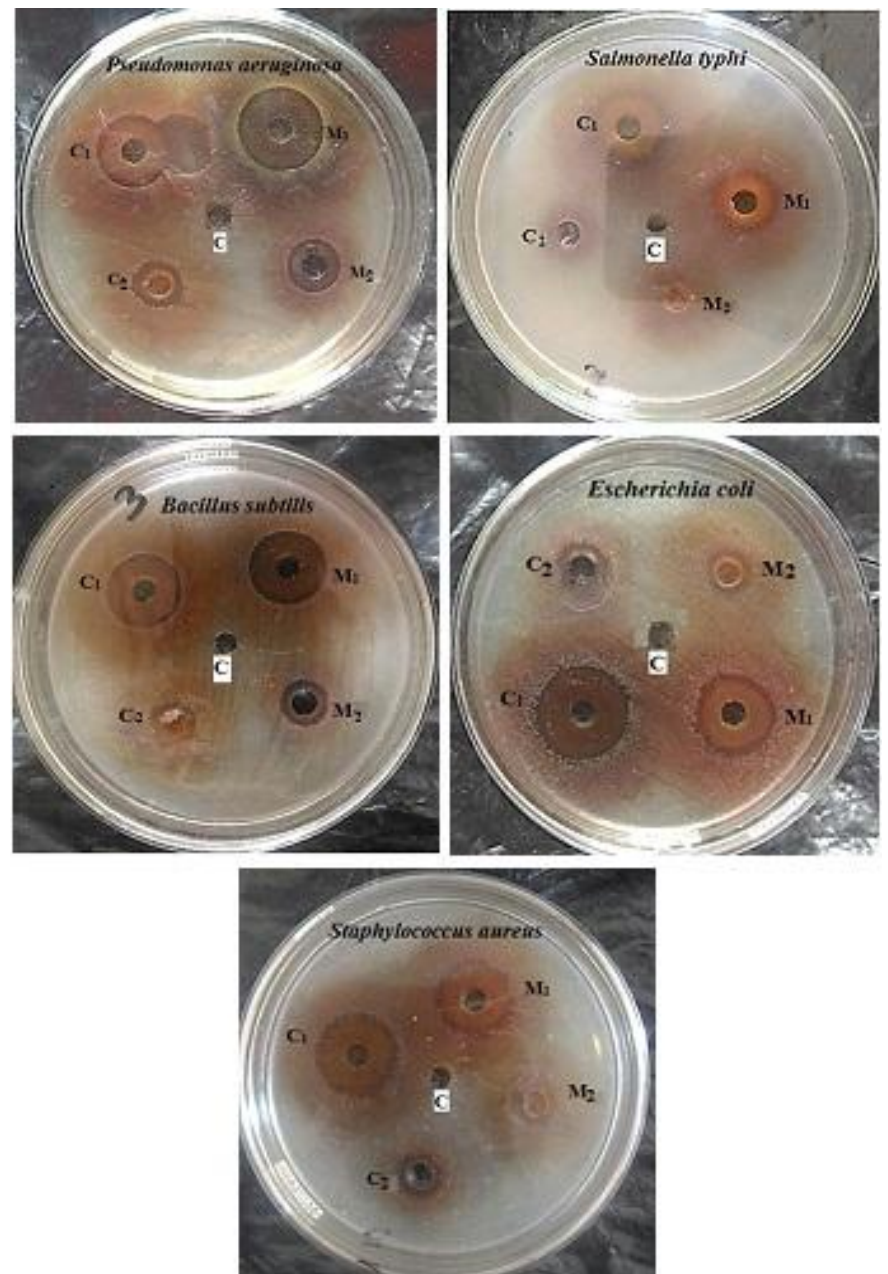

Fig. 3: Zones of inhibitions revealed by various plant parts of $A$. occidentale and M. indica against $P$. aeruginosa, S. typhi, B. subtilis, E. coli and S. aureus

$\mathrm{C}_{1}$ (Young leaves), $\mathrm{C}_{2}$ (Bark) - A. occidentale, $\mathrm{M}_{1}$ (Young leaves), $\mathrm{M}_{2}$ (Bark) - M. indica, C-control

In the case of B. subtilis, young leaf extract of $M$. indica showed maximum zone of inhibition of $24 \mathrm{~mm}$ compared to other plant extracts of A. occidentale. Young leaf extract of $A$. occidentale showed zone of inhibition $(23 \mathrm{~mm}$ ) against $E$. coli and $S$. aureus (Table 2 \& Fig. 3).

This study was also supported by early study; there the antibacterial activity of young leaves of $M$. indica against $S$. typhi was investigated. [25] This study also helped to find out new sources of natural antioxidants to use them in food industries and pharmaceutical industries to replace synthetic ones. Antibacterial activities of plant extracts have lot of therapeutic application to treat many infectious diseases and they also have fewer side effects related to synthetic drugs.

\section{ACKNOWLEDGEMENTS}

We thank to Dept. of Biotechnology, Sree Narayana College, Kollam, Kerala, India for providing laboratory facilities to carry out this work.

\section{REFERENCES}

1. Atawodi SE. Antioxidant potential of African medicinal plants. Afr J Biotechnol. 2005; 4(2): 128-133. 
2. Shyur, Lie-Fen, Tsung Jieh-hen, Chen Ie-Hsin, Chiu ChihYang, Lo Chiu-Ping. Antioxidant properties of extracts from medicinal plants popularly used in Taiwan. Int J Appl Sci Eng. 2005; 3(3):195-202.

3. Katalinic V, Milos M, Kulisic T, Jukic M. Screening of 70 medicinal plant extracts for antioxidant capacity and total phenols. Food chem. 2006; 94: 550-557.

4. Pratt DE. Natural antioxidant from plant material. In: IMT, Huang, CT. HO \& CY Lee (Eds). Phenolic compounds in food and their effects on health. New York American Chemical Society. 1992, pp. 54-72.

5. Klipstein K, Launer LJ, Geleijnse JM, Boeing H, Hofman A, Witterman JC. Serum carotenoids and antherosclerosis. Int Adv Pharm Biol Sci. 2000; 148(1):49-56.

6. Slattery ML, Benson J, Curtin K, Ma KN, Schacffer D, Pootter JD. Carotenoids and colon cancer. American Journal of clinical Nutrition. 2000; 7(2): 575-582.

7. Nugroho AE, Malik A, Pramono S. Total phenolic and flavonoid contents, and in vitro anti-hypertension activity of purified extract of Indonesian cashew leaves (Anacardium occidentale L.). International Food Research Journal 2013; 20(1): 299-305.

8. Jaiswal Y, Tatke P, Gabhe S, Vaidya A. Effect of Various Drying Methods on Antioxidant Activity and Catechin Content of Cashew Leaves. Int J Adv Pharm Biol Sci. 2012; 2(2):176-182.

9. Carmona F, Pereira AMS. Herbal medicines: old and new concepts, truths and misunderstandings. Braz J Pharmacognosy 2013; 23:379-85.

10. Prasannabalaji N, Muralitharan G, Sivanandan RN, Kumaran S, Pugazhvendan SR. Antibacterial activities of some Indian traditional plant extracts. Asian Pac J Trop Dis. 2012; 14: 2915.

11. Muthusamy R, Karthiga V, Lavanya K, Deboral P, Bernala W. Phytochemical screening and antibacterial activity of methanol extract of Tridax procumbens. International Journal of Pharmacy and Biological Sciences. 2013; (3)1: 521-524.

12. Harborne JB and Harborne AJ. Phytochemical methods: A guide to modern techniques of plant analysis. Kluwer Academic Publishers, London, UK. 1998.

13. Kumarasamy $Y$, Byres M, Cox PJ, Jasapars M, Nahar L and Sarker SD. Screening seeds of some Scottish plants for free radical scavenging activity. Phytother. Res. 2007; 21: 615-621.

14. Alzoreky NS, Nakahara K. Antibacterial activity of extracts from some edible plants commonly consumed in Asia. International Journal of Food Microbiology. 2003; 80: 223-230.
15. Bauer AW, Kirby WM, Sherris JC, Turck M. Antibiotic susceptibility testing by standardized single disc method. Am. J. Clin Pathol. 1996; 44: 493- 496.

16. Zhao H, Zhang H, Yang S. Phenolic compounds and its antioxidant activities in ethanolic extracts from seven cultivars of Chinese jujube. Food Science and Human Wellness. 2014; 3: 183-190.

17. Jaiswal Y, Vinayak N, Pratima T, Satish G, Ashok V. Pharmacognostic and preliminary phytochemical investigations of Anacardium occidentale (linn.) Leaves. International Journal of Pharmacy and Pharmaceutical Sciences. 2012; 4(3): 625-631.

18. Tan YP, Chiang CEW. Antioxidant, antityrosinase and antibacterial properties of fresh and processed leaves of Anacardium occidentale and Piper betle. Food Bioscience. 2014; 6: $17-23$.

19. Silva RA, Liberio SA, Amaral FM, Nascimento FRN, Torres LMB, Neto VM and Guerra RNM. Antimicrobial and Antioxidant Activity of Anacardium occidentale L. Flowers in Comparison to Bark and Leaves Extracts. Journal of Biosciences and Medicines. 2016; 4: 87-99.

20. Samba FN, Didier F, Blandine A, Mbaye DD, Rokhaya SG, Cheikh FS. Antioxidant and antiglycation properties of two mango (Mangifera indica L.) cultivars from Senegal. Asian Pacific Journal of Tropical Biomedicine. 2018; 8(3): 137-143.

21. Barreto JC, Trevisan WE, Hull G, Spiegelhalder R, Owen R. Characterization and quantitation of polyphenolic compounds in bark, kernel, leaves, and peel of mango (Mangifera indica L.). Journal of Agricultural and Food Chemistry. 2008; 56: 5599-5610.

22. Chbisika K, Sina H, Adoukonu SH, Ahoton LE, Roko, GO, Saidou A, Adeoti K, Ahanchede A. Antimicrobial activity of Anacardium occidentale L. leaves and barks extracts on pathogenic bacteria. African journal of microbiology research. 2014; 8(25): 2458-2467.

23. Sujatha S, Baby J, Antony ES. Analysis of Phytochemical Composition and Bio-activity Against Clinical Pathogens of Essential Oil from Anacardium occidentale (L.). Internet Journal of Food Safety. 2011; 13: 150-156.

24. Agedah CE, Bawo DD and Nyananyo BL. Identification of antimicrobial properties of cashew, Anacardium occidentale L. (Family Anacardiaceae). J. Appl. Sci. Environ. Manage. 2010; 14(3): 25-27.

25. Hannan A, Asghar S, Naeem T, Ikram Ullah M, Ahmed I, Aneela S, Hussain S. Antibacterial effect of mango (Mangifera indica Linn.) leaf extract against antibiotic sensitive and multidrug resistant Salmonella typhi. Pak J Pharm Sci. 2013; 2(4):715-719.

HOW TO CITE THIS ARTICLE: Sija SL, Athulya AS, Mahima MR, Vidhya A. Antioxidant and antimicrobial activity of different plant parts of Anacardium occidentale L. and Mangifera indica L.: a comparative study. Int. J. Pharm. Sci. Drug Res. 2019; 11(4): 111-115. DOI: 10.25004/IJPSDR.2019.110401 